International Journal of Industrial Engineering and Management (IJIEM), Vol. 9 No 3, 2018, pp. 139-146

Available online at www.iim.ftn.uns.ac.rs/ijiem_journal.php

ISSN 2217-2661

http://doi.org/10.24867/JJIEM-2018-3-139

\title{
Human Capital Investment: Practices and Measurement In Slovak Enterprises
}

\author{
Iveta Korobaničová \\ Assist. Professor, Faculty of Economics, Technical University of Košice, Letná 9, Košice, Slovak Republic, \\ iveta.korobanicova@tuke.sk \\ Nicoletta Kováčová \\ Faculty of Economics, Technical University of Košice, Letná 9, Košice, Slovak Republic
}

Received (28.09.2017.); Revised (26.03.2018.); Accepted (04.09.2018.)

\begin{abstract}
The issue of human capital in the present-day industrially and technologically driven society is becoming an increasingly hot topic. For enterprises in Slovakia thus it presents a challenge to respond to the current trends such as gradual robotization that will lead to the replacement of less qualified jobs by technology in the nearest years. For these reasons also, countries, enterprises or individuals must invest more in the development of human capital but at the same time take into account the return on this investment from the enterprises' perspective. The purpose of this paper is to find out how and how much time enterprises in Slovakia devote to the issue of the relationship between the development of human resources and investment in human capital. We also aim to explore whether enterprises assess this investment in human capital at all and in which way they do it. In this paper, we used quantitative research, namely a questionnaire method, which showed that enterprises in Slovakia do not largely invest in the development of their employees. Most companies invest in the development of employees by providing work-related training courses or by offering lectures, workshops and seminars. The results suggest that enterprises most frequently calculate remuneration costs and annual staffing costs that can be considered as traditional methods which, however, represent employees as companies' human resources being their liability not an asset they need to develop and invest into.
\end{abstract}

Key words: enterprises, human capital, human capital investment, measurement

\section{INTRODUCTION}

The development and education of human capital is a crucial factor in a learning society where enterprises can significantly participate in the development of their employees and support lifelong education [1]. There is a long-term shortage of specialists also in Slovakia, especially in the field of industrial production, software engineering, information technology as well as in retail and wholesale trade. The current situation is that more than half of graduates take jobs in other fields than those they were trained for, and, therefore, it is in the employers hands to provide professional preparation and education of employees [2]. Apart from that companies must realize that the development of their staff and appropriate investment in human capital bring about numerous benefits such as an increase in the quality of production and improvement of the services provided, increase in the performance and productivity, time reduction to implement new technology which could contribute to better use of equipment and systems, decrease the turnover rate and absenteeism of employees [3]. The main motivation for the company's management is an anticipated increase in the productivity and revenues [4]. Numerous empirical studies not only assume but also confirm that human capital positively influences the organizational performance, as, for example, a study by [5] which deals with the influence of human capital on the strategy and performance of big law firms in the USA. Similarly, a study by Chen et al. [5] proves the influence of human capital on the market value and profitability of companies registered on the regulated market in Taiwan, as well as other studies.

In Slovakia, Pilková et al. [6] based on the analysis of 2718 SMEs operating found positive significant relationships between VAIC $^{\mathrm{TM}}$ (Value added intellectual coefficient) and ROA as a proxy of value creation in 14 industries. They found out that Slovak enterprises in 10 out of 15 industries would benefit if they further invested in human capital: skills and knowledge of employees. An increase in economic performance is due to the relationship between the development of human resources and investment in human capital [7]. To make a decision regarding investment in company's human resources it is important to monitor human potential and assess the performance of employees [8], however, it is extremely difficult to measure and 
calculate the value of human capital in company accounts and annual reports [42]. This is because of the character of human capital which is an intangible asset with numerous dimensions [9], its value is not stable, but variable and dynamic. According to [10], in the know-how economy we should use and analyze data on human capital more extensively. However, the reality in companies is different, as proved by the results of the survey carried out by Accenture [11] which showed that many companies do not even attempt to measure their investment in human capital.

Despite the fact that the topic of human capital is very important and widely discussed in Slovakia authors [12][13] and others deal with this issue mostly in terms of company's performance taking into account intellectual capital or innovations. However, there is an obvious absence of research focused on measuring investment in human capital and its reporting. The above-mentioned reasons and research studies were the main motivators for the concept of this paper.

The aim of the present paper is to find out if companies consider it important to invest in the development of human capital and measure this investment as well as to investigate in which ways they are willing to invest in their employees. All these facts will help better understand the requirements of the labour market and trends in the area of human capital. In order to fulfill this aim, the paper is divided into several parts.

The first part suggests ways of investing in human capital in companies as well as most frequently used methods of measuring and reporting of investment in human capital. It is followed by the description of the data and methodology of the research with the main part of the paper focused on the research of the importance of investment in human capital as well as methods of its measurement in companies in Slovakia including supporting statistical metrics,. In the final part of the paper we present our conclusions.

\section{LITERATURE REVIEW}

The issue of human capital is discussed by many authors in terms of the theory of human capital $[13][14][15]$, social capital [16], marco-economy [5][13][14] or micro-economy [13][17] as well as other approaches [8]. The common feature of these studies is the fact that human capital represents a source of progress and economic growth, plays an important role in the development of each and every enterprise. Human capital is the source of innovation, changes, improvements [18] and strategic renewal [5]. Along with that it is also the most important asset of a company consisting of team professional knowledge, abilities to solve problems creatively, entrepreneurial and managerial skills [5].

According to [19], in today's competitive world, every organisation in order to have its competitive edge, takes part in the training and development of its human capital on a regular basis. According to [20], training of employees can be most often held on the job in the form of briefings, rotation of jobs, coaching, mentoring or off the job in the form of presentations, simulations, self-study, workshops, brainstorming, seminars, case studies, role play, managerial games, etc. In the practice of modern management of human resources, outdoor learning is a very popular method focused on building team spirit. Its disadvantage is that it is time and cost-consuming, for that reason it is usually used for managers in big organizations [21].

Another popular method is e-learning in which education and training are delivered through information technology [22]. Companies spend a lot of money on training and development, strategies to retain and motivate their employees in order to increase their performance and efficiency [23]. According to Becker [24], companies will invest in human capital if the expected marginal revenue from this investment equals the cost for this investment. However, for organizations there still exist significant problems with quantitative evaluation of the true impact of training on human capital of an organization [25]. In order to estimate and measure the investment made in the development and training of human capital, there is a growing requirement for some methods of quantifying the value of this investment [26]. In the previous era, this need for the measurement of cost and value of people as organizational resources gave rise to human resource accounting [27]. Human resource accounting (HRA) has been defined by [28] as „the process of identifying and measuring data about human resources and communicating this information to interested parties". Leigh [29] asserts that according to this approach the cost of training should account of the time spent "off the job" as well as the cost of providing the training and any other expenditure such as accommodation, etc. These costs should be comprised to fixed capital cost, depreciation of such equipment, working capital, personnel or administrative costs, training cost of trainers, cost of delivery, training development costs and travelling costs [30], which can be calculated using TIV (Training investment Value) indicator [31].

According to Dale [32], outputs from education can be also measured in the form of better morale, increased attendance, lower turnover and better retention, improved customer service, etc. From an accounting perspective, where the need for precise metrics is important, the measurement of human capital has proved challenging [33]. One of the ways to include human capital and others forms of intangible assets in a balance-sheet is to increase compatibility between the market and book value of a company [10].

The correct evaluation and subsequent booking of the intangible assets is important according to [34] who suggests that it will improve the ability of top management to more quickly execute the selected strategy through more effective use of human capital.

According to a few authors [26] [35], the capital investment appraisal techniques are practicable and top management is normally familiar with their use: ROI, bottom line evaluation, WACC (Weighted Average Cost of Capital), BCR (Benefit Cost Ratio). When calculating the return on investment in human capital enterprises can also take into account employee turnover, absenteeism, morale of employees [36] as well as other factors given in Table 1. 
Table 1. List of indicators of human capital investment Indicators In text-citation

Revenue per employee

$\mathrm{HC} \mathrm{ROI}$

ROT - Return on Talent

[37]

[31], [37], [38], [39]

[31], [40]

HEVA - Human Economic

HCVA

[39], [40]

Other indicators, e.g. Researchers citation in [41]

Gender ratio, Total training

hours and per employee,

Total training dollars and

per employee, ...

Less used tools include the indicator of human economic added value (HEVA), human capital added value (HCVA), HC vs RIO as shown in studies by [42],[43], [44]. According to the results of the study by [43] on the sample of 600 enterprises in Poland, the most frequent indicators of human capital include: costs related to the compensation of employees $(78,33 \%)$, absenteesim $(62,17 \%)$, costs associated with training of employees $(52,33 \%)$ and the least used indicators under $20 \%$ are attitudes of employees $(18 \%)$, return on investment in human capital $(16,33 \%)$ and economic value added of human capital (12,50\%). Enterprises that measure the return on investment in human capital give three reasons why it is essential to measure investment in human capital: the shortage of qualified employees has a negative impact on competitiveness and growth in the longer term, the need to measure human capital is related to the realization of the company's strategy and the perception of human capital as the most valuable and most important element of the functioning of society. According to the study by [45] of the total number (50) of Polish listed companies, around $80 \%$ of these companies indicated that their company collects data on human capital, $8 \%$ do not collect such data, and $12 \%$ is not able to determine whether their company collects information on human capital and/or its management.

In Slovakia, no research evidence has been found to examine the extent of $\mathrm{HC}$ reporting and forms of human capital investment in a larger group of enterprises. However, available studies [6] are limited to select a few companies or another kind of interest. Based on this theoretical background and empirical research the following research questions were formulated:

RQ1: What are the most common forms of investment in the development of employees in Slovak enterprises?

RQ2: What methods for measurement of investment in human capital do Slovak enterprises use?

\section{METHODOLOGY}

The present study has been undertaken to assess the adoption of human capital indicators in a sample of enterprises in Slovakia. The research conducted for purposes of this paper required collecting primary data by means of quantitative research, namely survey research by administering questionnaires to enterprises running businesses in Slovakia. The questionnaire was created using theoretical source materials and studies [43][45]. It was adapted for this research and included questions on the importance given to measuring human capital, existing measurement practice, and the importance given to measuring return on investment in human capital as well as typical forms of human resource development.

Both, checklists and open-ended questions were used in this survey instrument. The questionnaire was sent to 3300 enterprises in Slovakia, with 161 responses received, producing a response rate of almost $5 \%$.

The data were collected over the period from January 2018 to April 2018. The lower rate of response, according to [46], can be accounted for the fact that those receiving the questionnaire did not find measuring human resources an important enough topic to respond to or lower willingness to participate due to lack of time. The largest part of respondents, i.e. $62,1 \%$ were micro-enterprises with the number of employees from one to nine, $28,6 \%$ (SMEs) and $9,3 \%$ (large enterprises). (Table 2)

From the above-mentioned number of respondents who participated in the research $40 \%$ of enterprises provided services, $16 \%$ of respondents were engaged in industry, $12 \%$ in building industry and almost $11 \%$ of respondents in agriculture, $9 \%$ of respondents in trade, almost $6 \%$ in the field of ICT and about $3 \%$ in the field of education. The rest $3 \%$ of respondents were engaged in other branches.

\section{RESULTS AND DISCUSSION}

The following part presents the results of the research carried out in several areas.

\subsection{The importance of measuring human capital and investment to human resource development}

In this section, respondents (enterprises) were requested to indicate ( 1 - not important to 5 - very important) how important is the measurement of human resources to their enterprises and how important it is to invest into human resource development. On the whole, almost $50 \%$ of respondents consider investment in human capital as very important.

On the other hand, for almost $10 \%$ of respondents it is not important. As regarding the importance of measuring the return on investment in human capital, the results of the survey are different. $29 \%$ consider it as very important and almost $20 \%$ as important.

The value three was chosen by $36 \%$ of respondents which can be considered a neutral value. $14 \%$ of respondents consider measurement of return on investment in human capital less or not important. 


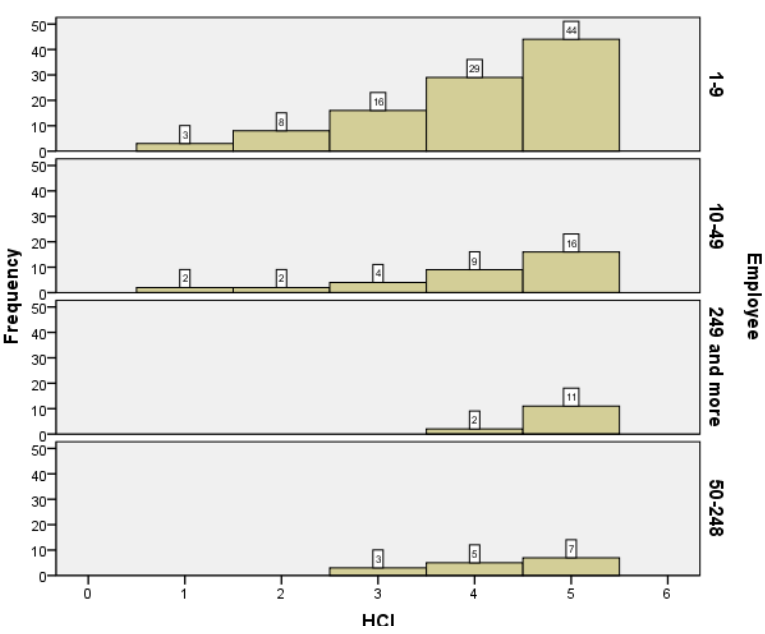

Figure 1. Importance of Measurement of Human Capital Investment in Slovak Enterprises

The figure 1 shows that for $84,6 \%$ of the large companies (249 and more employees) is very important to invest into human capital (and important for $15,4 \%$ of companies). On the contrary, the scale "very important" to invest into human capital was chosen only by around $46,4 \%$ of the other companies. Also, for $77 \%$ of large companies and around $67 \%$ of small companies are very important (and important) to measure the $\mathrm{HCl}$. Micro and medium companies were chosen neutral value. (Figure 2)

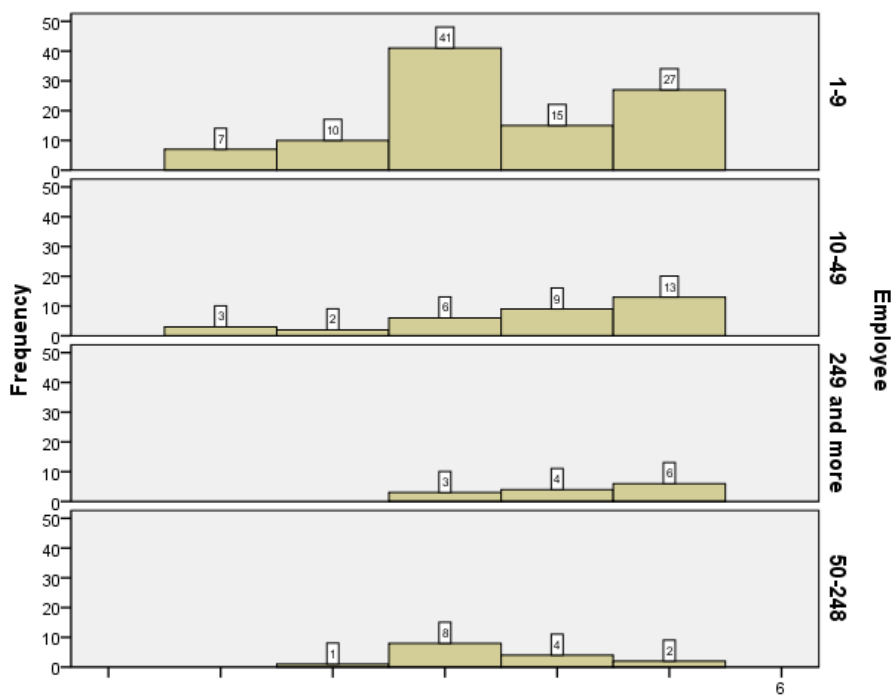

Figure 2. Importance of Measurement of Human Capital Investment in Slovak Enterprises

Table 2. Crosstabulation of employee ${ }^{\star}$ form in $\%$

\begin{tabular}{|c|c|c|c|c|c|c|c|c|c|}
\hline \multirow{2}{*}{\multicolumn{2}{|c|}{ Employee }} & \multicolumn{7}{|c|}{ Forms } & \multirow[t]{2}{*}{ Total } \\
\hline & & plc. & Contributory & Cooperative & $\begin{array}{l}\text { Non- } \\
\text { profit }\end{array}$ & Ltd. & $\begin{array}{l}\text { Self- } \\
\text { empl. }\end{array}$ & State & \\
\hline \multirow[t]{2}{*}{ Micro } & $\begin{array}{l}\text { \% within } \\
\text { employee }\end{array}$ & 3,0 & 0 & 0 & 0 & 82 & 15,0 & 0 & 100 \\
\hline & $\%$ within form & 17,6 & 0 & 0 & 0 & 68,3 & 83,3 & 0 & 62,1 \\
\hline \multirow[t]{2}{*}{ Small } & $\begin{array}{l}\text { \% within } \\
\text { employee }\end{array}$ & 9,1 & 0 & 6,1 & 3 & 75,8 & 6,1 & 0 & 100 \\
\hline & $\%$ within form & 17,6 & 0 & 100 & 100 & 20,8 & 11,1 & 0 & 20,5 \\
\hline \multirow[t]{2}{*}{ Medium } & $\begin{array}{l}\text { \% within } \\
\text { employee }\end{array}$ & 26,7 & 0 & 0 & 0 & 60,0 & 6,7 & 6,7 & 100 \\
\hline & $\%$ within form & 23,5 & 0 & 0 & 0 & 7,5 & 5,6 & 100 & 8,1 \\
\hline \multirow[t]{2}{*}{ Large } & $\begin{array}{l}\text { \% within } \\
\text { employee }\end{array}$ & 53,8 & 15,4 & 0 & 0 & 30,8 & 0 & 0 & 100 \\
\hline & $\%$ within form & 41,21 & 100 & 0 & 0 & 3,3 & 0 & 0 & 9,3 \\
\hline \multirow[t]{2}{*}{ Total } & $\begin{array}{l}\text { \% within } \\
\text { employee }\end{array}$ & 10,6 & 1,2 & 1,2 & 6 & 74,5 & 11,2 & 6 & 100 \\
\hline & $\%$ within form & 100 & 100 & 100 & 100 & 100 & 100 & 100 & 100 \\
\hline
\end{tabular}

\subsection{Human Resource Development}

When respondents were requested to identify the typical forms of human capital development in their organisation, $86 \%$ of enterprises invest the most in their employees by providing on-the-job training.

The second most common way of investment in the development of human capital is self-study used by $42 \%$ of enterprises.

We can draw a conclusion that enterprises place emphasis also on the development of social capital because almost $35 \%$ of enterprises invest in the development of $\mathrm{HC}$ through team building activities. On the contrary, around $3 \%$ of enterprises do not invest in their employees at all. (Figure 3)

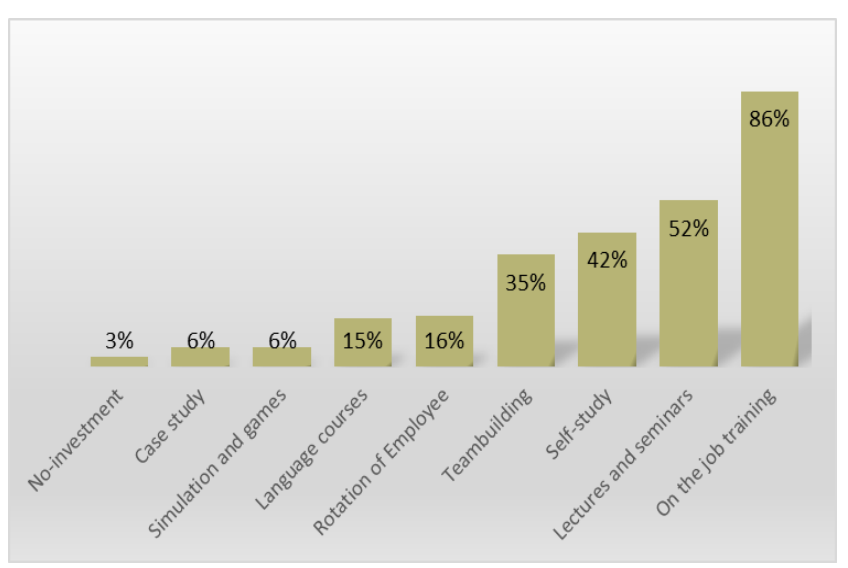

Figure 3. Forms of Human Resource Development in Enterpresis in Slovakia 
The Knowledge discovery in databases (KDD) method was used for further analysis of the data. This method is used in various areas in which databases are analyzed and groups of customers are identified along with predicting their behavior [47]. The obtained data were analyzed in SPSS Modeler Professional program (originally named SPSS Clementine), which provides data mining from structured data (KDD). Since the KDD model uses multiple functions for data mining, for the purposes of this paper we decided to use the so-called conjoint analysis which determines relationships between groups in the database [48]. (Figure 4)

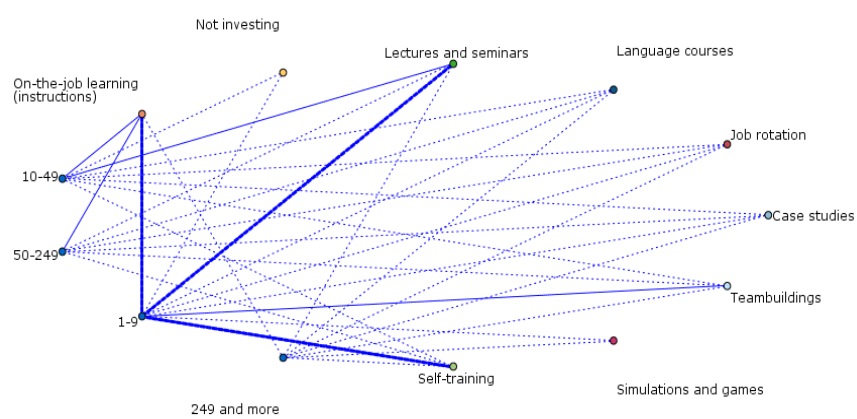

Figure 4. Forms of HRD in Slovak enterprises

As the figure 4 shows, the most common forms of staff development in micro- and small enterprises include training on-the-job, presentations and seminars as well as self-education of employees for their future career development. The larger the enterprise the more activities it provides to promote staff development, as the results of our study show, which, apart from the traditional forms of training, include to a greater extent rotation of employees to enhance their skills and knowledge as well as team building activities and language courses. In large enterprises, except simulation and case studies, all the above-mentioned forms of staff development are used in more than $60 \%$ of the analyzed enterprises.

\subsection{Measurement practices}

In this section, respondents were asked about the human capital measures that were utilized by their organisations. The respondents could mark indicators used by their company when measuring return on investment in human capital in a 17-item list. The most widely used method is determination of renumeration costs ( $80 \%$ of respondents) and annual costs per employee (76\% of respondents). It is not surprising that these measures used by a majority of organisations reflect the sorts of measures traditionally associated with human resource data collection and also include productivity of employees (75\% of respondents), efficiency and revenue per employee $(64 \%$ of enterprises). The least used tools for this sample of enterprises are indicators of return on investment in human capital (e.g. ROI vs HC, HCVA, etc.) (23\%), the costs associated with staff rotation (17\%), economic added value per employee (45\%). However, from the above-mentioned sample of companies, these are large enterprises that use tools for measuring the return on investment in human capital to a much greater extent $(30,8 \%)$, but at the same time assess their investment in human capital through multiple metrics paying for expenses on training and education, remuneration of employees, they also keep records of annual costs for employees. Medium enterprises compared to large companies focus on the productivity and efficiency of employees similarly as micro and small enterprises. (Table 3)

Table 3. Tools of Measurement of the Human Capital Investment in Slovak Enterprises

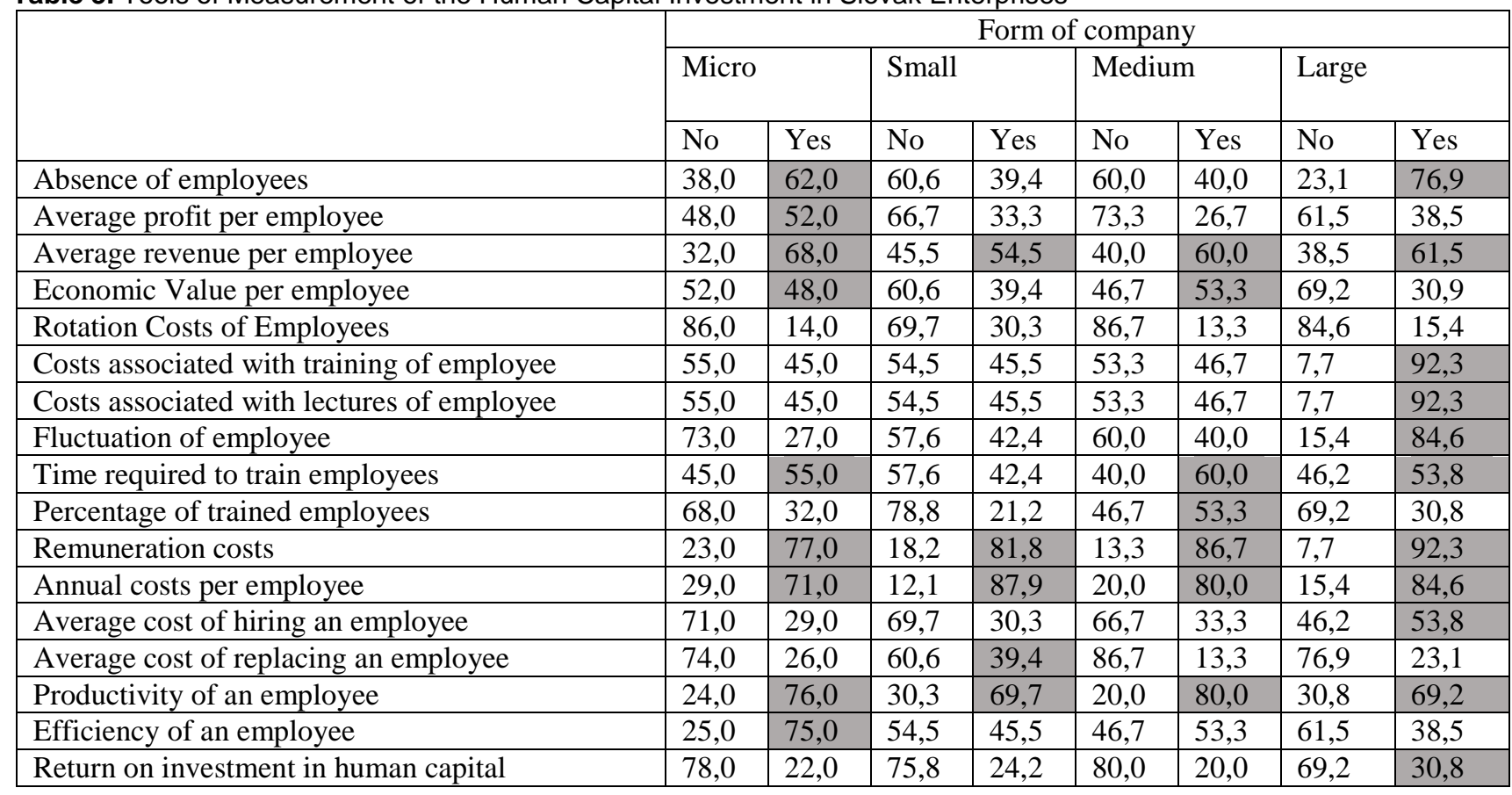


The analysis shows that enterprises are most of all interested in how much employees cost them and if they are productive and efficient. According to [42], efficiency is used most often to describe the results of an enterprise and contributes to the development of activities aimed at achieving objectives or improving results.

\section{CONCLUSION}

The findings presented above demonstrate that most of the companies in Slovakia (83\%) collect basic information about their employees for the purposes of keeping personnel records. To a much lesser extent, enterprises collect information about newly hired staff and employees who terminated their employment (around 20\% of respondents) as well as the number of employees who were provided education in that year (around $16 \%$ of respondents).

From the analysis of empiric results we come to a conclusion that the majority of companies invest in the development of employees providing on-the-job education and training in the form of briefings and consultations. Enterprises in Slovakia in general do not use active methods of education, but rather traditional ones based mostly on one-sided communication, thus proving the results reported by [20].

On the other hand (research question 2), the results show that companies most often measure investment in human capital based on remuneration costs, annual costs per employee and productivity of their employees. Return on investment is neither an important nor unimportant tool for measuring return on investment, enterprises adopted a neutral attitude. We can conclude that enterprises in Slovakia perceive their employees as a cost rather as an asset to be developed through investment. We can also state that these enterprises use more traditional measures of human resources. The use of traditional human resource measures (i. e. remuneration costs, absenteeism of employees, productivity of employees, time required for their training, etc.) reflect the first phase in the measurement process [46] and allows enterprises to focus on "hard" measures of human capital (e.g. economic added value per employee, return on investment in human capital, etc.) It will help enterprises get an overview about the value of human capital and potential opportunities for further investment and its return. Cantrell et al. [11] pointed out that societies with advanced processes of human capital have better financial performance than those with less developed processes. Advanced processes do not have to influence financial performance immediately; at first they influence the abilities of human capital such as engagement and efficiency of employees which affect the key factors of performance[11].

\section{ACKNOWLEDGEMENT}

This work was supported by the Slovak Research and Development Agency under the contract No. APVV-140512 - Universities and economic development of regions.

\section{REFERENCES}

[1]. Antošová, M. and Csikósová, A. (2008), “Trendy rozvoja l'udského kapitálu v globalizujúcom sa svete", avalaible at: http://ua-

ed.narod.ru/AEDUCA 2008/SOUBORY/MAN/MAN01Antosova Csikosova.pdf (accessed: 31 March 2018).

[2]. Proplusco, (2018), "Prečo si firmy musia sami vzdelávat' svojich zamestnancov?, avalaible at: https://proplusco.sk/blog/preco-sifirmy-musia-sami-vzdelavat-svojich-zamestnancov (accessed: 15 April 2018).

[3]. Drábek, J. et al. (2017), "Investing in Human Capital as a Key Factor for the Development of Enterprises", INTECH, Chapter 6, avalaible at: https://www.intechopen.com/books/issues-ofhuman-resource-management/investing-in-human-capital-as-akey-factor-for-the-development-of-enterprises (accessed: 15 April 2018).

[4]. Bae, S. O. and Patterson, L. (2014), "Comparison and Implications of Human Capital Theory at the Individual, Organization and Country Levels", Journal of Organizational Culture, Communications and Conflict, Vol. 18, No. 1, pp. 11 28.

[5]. Scafarto V. et al. (2016), "Intellectual capital and firm perfomance in the global agribusiness industry: The moderating role of human capital.", Journal of Intellectual Capital, Vol. 17, No. 3, pp. 530-552.

[6]. Pilková, A., Volná, J., Papula, J. and Holienka, M. (2013), "The Influence of Intellectual Capital on Firm Performance Among Slovak SMEs" in Proceedings of the 10th International Conference on Intellectual Capital, Knowledge Management and Organisational Learning. Reading: Academic Conferences and Pubslihing International Limited. pp. 329-338.

[7]. Urbančíková, N. (2006), "L'udské zdroje v regionálnom rozvoji", 1. Edition, Košice: C-Press.

[8]. Babel'ová Gyurák, Z. (2011), "Effectiveness of investments into human resources development in Slovakia“, avalaible at: https://books.google.sk/books?hl=sk\&lr=\&id=2srdrRahEskC\&oi =fnd\&pg=PA5\&dq=effectiveness+of+investments+into+human+ resources+development\&ots $=$ EU2tqtTbpL\&sig=FAZFKEP3eAO olSXHHTsO_FhmBsA\&redir_esc=y\#v=onepage\&q\&f=false > (accessed: 31 March 2018).

[9]. Robinson, D. (2009), "Human capital measurement: an approach that Works“, Strategic HR Review, Vol.8, No. 6, pp. 511.

[10]. Ahonen, G. (2009), "On the mystery of odd human capital values", Journal of Human Resource Costing \& Accounting. Bradford, Vol. 13. No. 2, pp. 118-124.

[11]. Cantrell, S. et al. (2006), "Measuring the value of human capital investments: the SAP case“, Strategy \& Leadership; Chicago. Vol. 34, No. 2, pp. 43-52.

[12]. Rajnoha, R. and Lorincová, S. (2015), "Strategic Management of Business Performance Based on Innovations and Information Support in Specific Conditions of Slovakia", Journal of Competitiveness. Vol. 7, Issue 1, pp. 3 -21. DOI: 10.7441/joc.2012-01.01

[13]. Rajnoha, R., Lesníková, P. and Korauš, A. (2016), "From Financial Measures to Strategic Performance Measurement System and Corporate Sustainability Empirical Evidence from Slovakia", Economics and Sociology, Vol. 9, No. 4, pp. 134152. Nerdrum, L and Erikson, T. (2001), "Intellectual capital: a human capital perspective", Journal of intellectual Capital, Vol. 2, No. 2, ppr. 127-135.

[14]. Laroche, M. (1998), "On the Concept and Dimensions of Human Capital in a Knowledge-Based Economy Context", Canadian Public Policy, Vol. 25, No. 1, pp. 87-100.

[15]. Teixeira, P.N. (2014), "Gary Becker's early work on human capital - collaborations and distinctiveness", Journal of Labor Economics, No. 3, pp. 1-20.

[16]. CIPD (2017), "Human capital metrics and analytics: assessing the evidence of the value and impact of people data", avalaible at: https://www.cipd.co.uk/Images/human-capital-metrics-andanalytics-assessing-the-evidence tcm18-22291.pdf (accessed: 31 March 2018).

[17]. Massingham, P. et al. (2011), “Using 360 degree peer review to validate self-reporting in human capital measurement", Journal of Intellectual Capital, Vol. 12. No. 1. pp. 43-74. 
[18]. Massingham, P. R. and Tam, L. (2015), "The relationship between human capital, value creation and employee reward", Journal of Intellectual Capital, Vol.16, No. 2, pp. 390-418.

[19]. Subedi, B. S. (2006), "Cultural factors and beliefs influencing transfer of training", International Journal of Training \& Development, Vol. 1, No. 2, pp. 82-90.

[20]. Matulčíková, M. (2017), “Uplatňovanie metód vzdelávania $v$ d'alšom profesijnom vzdelávaní zameranom na podporu ekonomickej gramotnosti zamestnancov v zdravotníctve", Societa set iurisprudentia, Volume 5, No. 2, pp. 142-161.

[21]. Czikk, P. and Čepelová, A. (2006), "Vzdelávanie a rozvo pracovníkov", Manažment v teórii a praxi, Vol. 2, No. 2. avalaible

http://www.scss.sk/smpmcd/files/semestralne projekty1/person alna\%20strategia\%20podniku/casopis\%20euke\%20\%20cepelova.pdf (accessed: 4 April 2018).

[22]. Urban, J. (2005), "Pojmy dôležité pre personalistov a manažérov", avalaible https://hnporadna.hnonline.sk/moja-kariera/178398-pojmy dolezite-pre-personalistov-a-manazerov (accessed: 4 April 2018).

[23]. Kaur, S., Venkat Raman, A. and Singhania, M. (2014), "Human Resource Accounting Disclosure Practices in Indian Companies", Sage Publications, Vision 18, No. 3, pp. 217-235.

[24]. Welpe, I. et al. (2007), "The Theory of Real Options as Theoretical Foundation for the Assessment of Human Capital in Organization", Zeitschrift fur Personalforschung. Munchen. 2007, Vol. 21, No. 3. pp. 274-294.

[25]. Wagar, T. H. (1997), "Determinants of formal training in large Canadian organizations", International Journal of Training \& Development, Vol. 1, No. 2, pp. 82-90.

[26]. Chaudhry, lqbal N. and Roomi, Azam M. (2010), “Accounting for the development of human capital in manufacturing organizations. A study of the Pakistani textile sector.", Journal of Human Resource Costing \& Accounting, Vol. 14, No. 3, Emerlad Group Publishing Limited 1401-338X.

[27]. Flamholtz, E. G. (1999), "Human Reource Accounting, Advances in Concepts, Methods, and Applications", 3rd ed. Kluwer Academic Publishers, Boston, MA

[28]. American Accounting Association (1973), "Report of the committee on human resource accounting", The Accounting Review, Vol. 48, pp. 169-85.

[29]. Leigh, D. (2005), "Encyclopaedia of Practical Management Training", Crest Publishing House, Charlotte, NC.

[30]. Campbell, C. (1994), "A primer on determining the cost effectiveness of training - Part 1.”, Industrial \& Commercial Training, Vol. 26, No. 11, pp. 32-38.

[31]. Kucharčíková et al. (2015), "Efektívnost' investícií do ludského kapitálu”, Journal of Management and Economics. Č.1/2015. Str. 43-56.

[32]. Dale, M. (2004). Developing Management Skills: A Handbook. Kogan Page India, New Delhi.

[33]. McCracken, M., Mclvor, R., Treacy, R., Wall, T. (2018), "A study of human capital reporting in the United Kingdom", Accounting Forum, Vol. 42, pp. 130-141.
[34]. Schiemann, W. A. (2007), "Measuring and Managing The ROI of Human Capital", Cost Management; Vol. 21, No. 4, pp. 5-15.

[35]. Flamholtz, E. G. and Bullen, M. L. (2003), "Measuring the ROI of management development", Journal of Human Resource Costing \& Accounting, Vol. 7, No. 2, pp. 21-40.

[36]. Wilson, P. (2001), "The human investment: What's your ROI on pepople?”, CMA Management; Hamilton, Vol. 75, No. 7, pp. 2729.

[37]. Duong T. et al. (2017), "EBITDA/NIBBT/revenue/turnover/profit per employee, HC retun on investment”, avalaible at: http://www.orga.uni-sb.de/w/wp-

content/uploads/2017/02/HC Performance2.pdf (accessed: 24 March 2018).

[38]. Poddar, S. (2015), "Return on Investment (ROI) on Human Capital, .avalaible at: https://www.linkedin.com/pulse/returninvestment-roi-human-capital-sarajit-poddar-gphr-hrmp (accessed: 29 March 2018).

[39]. Fitz-Enz, J. (2009), "The ROI of Human Capital", Library of Congress Cataloging, Amacom, New York: 2009. 2nd edition. 312 pages.

[40]. Ďurian, J. (2012), “Ukazovatel'-základný kameň systému personálneho kontrolingu", avalaible at: http://www.mktraining.sk/ukazovatel-zakladny-kamen-systemupersonalneho-kontrolingu (accessed: 28 March 2018).

[41]. Rompho, N. (2017), "HC and financial performance with two HRM strategies", International Journal of Productivity and Performance Management, Vol. 66, No. 4., pp. 459-478.

[42]. Bagienska, A. (2015), "Measurement and analysis of the efficiency of human capital in a small enterprise in Poland", Financial Internet Quarterly, e-Finanse, Rzeszów, Vol. 11, No. 2, pp. 1-9.

[43]. Sienkiewicz, L. (2014), "Human Capital Measurement Practices in Polish Companies Empirical Evidence", European Conference on Intellectual Capital; Kidmore End, Academic Conferences International Limited, Apríl 2014, pp. 217-225.

[44]. Bryl, Ł. and Truskolaski, S. (2017), "Human Capital Reporting and Its Determinants by Polish and German Publicly Listed Companies", Entrepreneurial Business and Economics Review, Vol. 5, No. 2, pp. 195-210.

[45]. Żarnik-Żulawska, J. (2016), "Measurement of Human Capital and Market Value of Listed Companies", Journal of Positive Management, Vol. 7, No. 3. pp. 81-95.

[46]. Verma, S. and Dewe, P. (2008), "Valuing human resources. perceptions and practices in UK organisations", Journal of Human Resource Costing \& Accounting, Vol. 12, No. 2, pp. 102-123.

[47]. Lu, Y. H., Tsai, Ch. F. and Yen, D. C., (2010), "Discovering Important Factors of Intagible Firm Value by Association Rules", The International Journal of Digital Accounting Research, Vol. 10, pp. 55-85.

[48]. Fayyad, U., Piatetsky-Shapiro, G. and Smyth, G. (1996), "From datamining to Knowledge Discovery on Database, Rhode Island: American Association for Artificial Intelligence, available at:

https://www.aaai.org/ojs/index.php/aimagazine/article/vie wFile/1230/1131

\title{
Investicije u ljudski kapital: prakse i merenja u slovačkim preduzećima
}

\author{
Iveta Korobaničová, Nicoletta Kováčová
}

Primljen (28.09.2017.); Recenziran (26.03.2018.); Prihvaćen (04.09.2018.)

\begin{abstract}
Apstrakt
Ljudski kapital u današnjem industrijskom i tehnološkom društvu postaje sve vrelija tema. Stoga, za preduzeća u Slovačkoj ovo predstavlja izazov da se odgovori na aktuelne trendove kao što je postepena robotizacija koja će dovesti do zamene manje kvalifikovanih radnih mesta, posmatrano iz tehnološkog aspekta, u narednim godinama. Zbog ovih razloga, zemlje, preduzeća ili pojedinci moraju uložiti više u razvoj ljudskog kapitala, ali u isto vrieme uzeti u obzir povraćaj ove investicije iz perspektive preduzeća. Svrha ovog rada je da prikaže kako i koliko vremena preduzeća u Slovačkoj posvećuju pitanju odnosa između razvoja ljudskih resursa i ulaganja u ljudski
\end{abstract}


kapital. Takođe, cilj ovog rada je da istraži da li preduzeća uopšte procenjuju ovu investiciju u ljudski kapital i na koji način to rade. U ovom radu korištena su kvantitativna istraživanja, odnosno metoda upitnika, koja je pokazala da preduzeća u Slovačkoj u velikoj meri ne investiraju u razvoj svojih zaposlenih. Većina kompanija investira u razvoj zaposlenih tako što pruža kurseve/obuke u vezi sa delatnošću ili organizuje predavanja, radionice $i$ seminare. Rezultati ukazuju na to da preduzeća najčešće izračunavaju troškove naknada i godišnje troškove osoblja, koje se mogu smatrati tradicionalnim metodama, koje međutim, predstavljaju zaposlene kao ljudske resurse preduzeća, smatrajući da njihova odgovornost nije investiranje u razvoj ovog resursa na višem nivou.

Ključne reči: preduzeća, ljudski kapital, investicije u ljudski capital, merenje 